\title{
Celebration of Excellence in Teaching: What is Your Philosophy?
}

\author{
Libby V. Morris
}

Published online: 10 January 2015

(C) Springer Science+Business Media New York 2015

The University of Georgia's Teaching Academy celebrates its $15^{\text {th }}$ anniversary this fall. The Academy began in 1999 with 13 charter members as part of an initiative by the Carnegie Foundation for the Advancement of Teaching and the American Association for Higher Education to launch teaching academy campus programs nationwide. Today, with more than 100 members, the UGA academy promotes excellence in teaching through workshops, symposia and other events; assists with university level instructional awards; and receives funding for special events from the Office of the President and the Senior Vice President for Academic Affairs.

Each fall the academy inducts new members from nominations or being the recipient of a major university-wide teaching award. New inductees are asked to write a two page statement of their teaching philosophy. It is my joy to read these statements: I am struck by the thoughtful, engaged, and creative faculty at the University of Georgia. Their statements show an in-depth careful consideration of their educational beliefs and pedagogy. This fall, as I read the 11 personal statements, the word "engagement" stood out. The newly elected members and former teaching scholars describe a strong passion for their disciplines, interest in the student experience and perspective, and acknowledgement of the importance of student growth and development into the future. I hope you will be inspired by a few brief quotes from former and soon-to-be Teaching Academy members.

On the importance of engagement in teaching and learning...

- If I had to reduce my teaching philosophy to a single word, it would be "engagement." My goal is to engage students - to keep them actively thinking about the material and its applications. The tricky part is figuring out how to keep them engaged. (Law professor)

- Outstanding teaching, in my view, requires reflection more than anything else. It requires time and space and energy, much like academic writing. (Psychology professor)

- Most of all, enjoy the teaching experience. If I love what I do in class, then most of the students will understand the importance of the subject. Some will also come to love it. (Music professor)

- My aim in the classroom can be summed up with an oft-cited motto from E.M. Forster's novel, Howard's End: "Only Connect."...In my classes I work to make personal

L. V. Morris $(\triangle)$

Institute of Higher Education, University of Georgia, 102 Meigs Hall, Athens, GA 30602-6772, USA

e-mail: lvmorris@uga.edu 
connections with students and encourage them to connect directly with the subjects we study. (English professor)

- My own approach to teaching mathematics has always been a form of storytelling. Of course there are always specific skills and content that must be discussed and learned; but, unless I help to provide a story, they are dry and lifeless and probably best left to a computer. (Mathematics professor)

On the role of the student experience...

- The successful teacher is not one who simply has all the right answers coupled with pristine oratorical skills through which he dispenses them. I believe the successful teacher is one who is willing to not only reach out to the student but to reach into the student's experience. (Music Professor)

- My teaching is based on the principle that each student's background and experience is a key to their learning experience... whether it is dance history, ballet techniques or another course. (Dance professor)

- While students and new professors alike understand that learning content is paramount to the success in a course, it is the seasoned professor who understands that skills, abilities, and attitudes are of equal or greater importance in the student's educational development. (Pharmacy professor)

- My philosophy of teaching is built around some pretty simple tenants. First, I (the teacher) have to believe in what I am teaching. Second, I have to enjoy what I am doing. Third, students need to experience what they are learning. (Financial Planning and Consumer economics professor)

- I had great teachers who lectured, great teachers who engaged their classes in lively discussion, and great teachers who challenged students through rigorous Socratic questioning. My best teachers...were enthusiastic about their subjects and were able to convey their enthusiasm to their students. They enjoyed being in the classroom. All had a sense of humor and could laugh at themselves, and they treated students with respect and showed that they wanted us to understand the material. (Law Professor)

On looking past the course...

- I make efforts to understand the challenges they face; I believe that most of my students know and appreciate that I care deeply about their performance in class today, on the exam next week, and in life long after my class is over. (Veterinary Medicine professor)

- I want students to learn to make connections across disciplinary, national, and cultural borders - today's undergraduates will occupy workplaces and communities that have been transformed by globalization. (Biological and Agricultural engineering professor)

On joining the class of 2004, I wrote, "The educator teaches the student, not the content. The instructor should approach the responsibility to teach - to bring about learning, to change individuals - with joy, humility, and honor."

As I work on preparing a new course for next semester, these aforementioned quotes are inspiring to me. I considered my philosophy again and how it will shape the course. I hope you will find time to consider your teaching philosophy anew and that you will visit the homepage of the UGA Teaching Academy. The academy is wonderful community of scholars on my campus, and I hope you have a similar group at your institution. 


\section{Resources}

The University of Georgia Teaching Academy: http://teachingacademy.uga.edu/

Teaching Academy selected quotes: http:/teachingacademy.uga.edu/category/members/ 